\title{
Biological mixing responses to sublethal concentrations of DDT in sediments by Heteromastus filiformis using a ${ }^{137} \mathrm{Cs}$ marker layer technique
}

\author{
S. Mulsow ${ }^{1, *}$, P. F. Landrum ${ }^{2, * *}$, J. A. Robbins ${ }^{2}$ \\ ${ }^{1}$ Case Western Reserve University, Department of Geological Sciences, 10900 Euclid Ave, Cleveland, Ohio 44106, USA \\ ${ }^{2}$ Great Lakes Environmental Research Laboratory, NOAA, 2205 Commonwealth Blvd., Ann Arbor, Michigan 48105, USA
}

\begin{abstract}
Sediment mixing by benthic macroinvertebrates is an important process affecting the fate of sediment-bound and dissolved contaminants in marine environments. A non-invasive, stateof-the-art radiotracer technique was used to study sediment mixing by Heteromastus filiformis (Capitellidae), a common marine head-down deposit feeder, exposed to several sub-lethal concentrations of DDT $\left(0,5,10\right.$ and $20 \mu \mathrm{g} \mathrm{g}^{-1}$; control, Treatments 1, 2 and 3). Several horizontal submillimeter layers of ${ }^{137} \mathrm{Cs}$-labeled clay were deposited approximately every $2 \mathrm{~cm}$ in each of 3 replicate sediment columns per treatment; 4 polychaetes were then introduced to each column and the $\gamma$ activity of each column was measured vertically using an automated scan detector. Nonlinear leastsquare fits were applied to obtain parameterized values that were used to determine the mixing rates of each ${ }^{137} \mathrm{Cs}$ layer over time. A simple diffusion model was used to calculate biological diffusion coefficients $\left(D_{\mathrm{b}}\right)$ for $H$. filiformis. Overall mixing rates increased towards the surface. Control and Treatment 1 had higher $D_{\mathrm{b}}$ values at the surface compared to Treatments 2 and 3 . The $D_{\mathrm{b}}$ depth profiles were similar in the control and Treatments 1 and 2, with mixing occurring at the sediment water interface and a subsurface maximum at 10 to $12 \mathrm{~cm}$ below this interface. This pattern was not clear in Treatment 3, where $D_{\mathrm{b}}$ had the lowest values and decreased with depth. Bioturbation besides mixing of solids also changed the water content throughout the sediment column. Porosity profiles at the end of the experiments increased by 10 to $20 \%$ at 10 to $12 \mathrm{~cm}$ depths compared to above and below this horizon. The DDT depth concentration profiles decreased towards the surface as a result of the mixing by the benthic macroinvertebrates, clearly indicating removal/uptake by the organism. The feeding rate constant $\left(\gamma_{b}, \% h^{-1}\right)$ in the control showed a maximum at 7 to $12 \mathrm{~cm}$. However, the $\gamma_{b}$ in the treatments was essentially constant with depth. For all treatments and the control, the burial rate $\left(W_{\mathrm{b}}\right)$ (downward movement of radiolabeled layers) decreased with depth. The surface layers were buried faster (ANOVA, $\mathrm{p}<0.05$ ) in the control than in sediments containing DDT. A sensitivity analysis comparing burial rate, $D_{\mathrm{b}}, \gamma_{\mathrm{b}}$ (surface only) and worm weights showed that worm weights and burial rate have the highest fractional rate changes per $\mu \mathrm{g} \mathrm{g}^{-1} \mathrm{DDT}$.
\end{abstract}

KEY WORDS: Bioturbation $\cdot$ Heteromastus filiformis $\cdot$ DDT $\cdot$ Sediment contamination Resale or republication not permitted without written consent of the publisher

\section{INTRODUCTION}

Ecological studies of marine deposit feeders, particularly conveyor-belt deposit feeders (Rhoads 1974), have suggested that such organisms play an important role in the consumption and burial of solid and dissolved organic matter during early diagenesis (Aller 1980, Berner 1980, Levinton 1989, Gilbert et al. 1995).
These deposit feeders ingest sediments at $10 \mathrm{~s}$ of $\mathrm{cm}$ below the surface and deposit ingested particles as feces at the sediment-water interface. One of the

\footnotetext{
${ }^{*}$ Present address: International Atomic Energy AgencyMarine Environmental Laboratory, PO Box 800, Monte Carlo 98000, Monaco

${ }^{* *}$ Corresponding author. E-mail: peter.landrum@noaa.gov
} 
effects of such behavior is that it favors the interaction of reduced chemical species buried deep in the sediments with well-oxygenated overlying waters after passing through the digestive tract of the worms. This conveyor-belt-feeding process affects stratigraphic records as well as promotes changes in the chemical properties of bottom sediments (McCall \& Tevesz 1982). Because of the ecological role of these organisms, it is important to study their responses to environmental stressors caused by anthropogenic contaminants in estuarine and marine coastal environments (Dexter \& Pavlou 1973, Hom et al. 1974, Elder et al. 1976, Heemkem et al. 2000). For example, the latter authors reported an increase in organic micro-contaminant concentration, particularly DDT, since 1991 in the Elbe River. Further, Cantillo et al. (1997) showed a clear relationship between DDT and its metabolite concentrations in sediments and sources (agricultural areas) in south Florida. Although the trend indicated a decreasing concentration in sediment with time (1990 to 1991), biota did not follow the same temporal tendency.

Organic contaminants (e.g. DDT, endrin, aldrin, PCBs, PAHs) are strongly bound to the organic matter fraction of suspended particles and bottom sediments (Rice et al. 1993, Heemken et al. 2000). Because these contaminants are highly refractive, they are characterized by a long residence time after deposition. The half-life of DDT in soil is 2 to $15 \mathrm{yr}$ and $\sim 150 \mathrm{yr}$ in aquatic ecosystems (HSDB 1998). Thus, these sediment-associated persistent contaminants are potentially available to benthic organisms even after they are no longer produced (Frankel 1995) or introduced into the aquatic environment. DDT and its metabolites as well as PCBs are still found in bottom sediments and bottom-feeding fish from coastal areas at concentrations in the $\mathrm{ng} \mathrm{g}^{-1}$ lipid range (Young et al. 1977, 1991, Verschueren 1983, Marcus \& Renfrow 1990). Also, remarkably high levels of DDT (1446 $\mathrm{ng} \mathrm{g}^{-1}$ lipid weight) have been reported for deep-sea fishes in the Arctic, such as Macrurus berglax, which feed mostly on benthos at depths of $2000 \mathrm{~m}$ (Berg et al. 1997). Similar and somewhat higher values have also been reported for deep-sea fishes in other parts of the world (Takahashi et al. 1998).

The fate of compounds deposited at the sedimentwater interface will depend on a complex combination of sediment properties, xenobiotic chemical characteristics and physical variables as well as on the activity patterns of the dominant benthic communities. Rates at which sediments are ingested, deposited and subsequently re-buried have been mainly studied with freshwater invertebrates under both field and laboratory conditions (Fisher et al. 1980, McCall \& Fisher 1980, Krezoski 1981, Robbins et al. 1984, Keilty et al. 1988a,b). Most research on marine invertebrates involving chlorinated hydrocarbon contaminants has focused on contaminant bioaccumulation and depuration processes (Fowler et al. 1978, Elder et al. 1979, Schiff 1991). Marine biological mixing studies have been described in terms of the activities of major mixing organisms (see Rhoads 1974, Thayer 1983 for extensive reviews). These activities have usually involved measurements of the volume or mass of fecal pellets produced (Rhoads 1963, Appleby \& Brinkhurst 1970, Hylleberg 1975, Cammen 1980, McCall \& Fisher 1980, Whitlach \& Weinberg 1982, Lopez \& Cheng 1983, Thayer 1983, Rice et al. 1986) or of marked horizons made out of various tracers, such as luminophores (Mahaut \& Graf 1987), pollen grains (Davis 1974), copepods eggs (Marcus \& Schmidt-Gegenbach 1986), exotic sedimentary minerals (Aller \& Dodge 1974, McCall \& Fisher 1980, Rice 1986, Olmez et al. 1994) and radioactively labeled particles (Amiard-Triquet 1974, Haven et al. 1981, Santschi et al. 1984, Sorokin 1986). Changes in the amount of fecal pellets produced gives a rough estimate of surface sediment movements. With the exception of rare earth and radioisotopes, most of the particulate markers fall short of the sensitivity required for measuring bioturbation since their concentration, once it reaches the zone of maximum mixing/feeding, becomes too low to reveal the details of the mixing processes. Methods that are more sensitive are therefore necessary to fully understand the mixing activities of marine and freshwater organisms.

One application of more sensitive techniques for the study of biological mixing has been the use of radioisotope tracers. These studies have focused on the impact of contaminants on mixing processes in oligochaetes exposed to sediment-bound endrin (Keilty et al. 1988a,b) under laboratory conditions. The effects of a contaminant on biological mixing of sediments by marine invertebrates has only been inferred from ${ }^{234} \mathrm{Th}$ sediment profiles at the community level (Wheatcroft \& Martin 1996); thus, direct cause-effect relationships cannot be drawn from these studies. Mulsow \& Landrum (1995) have shown that Heteromastus filiformis, a common and abundant $\left(10^{3}\right.$ to $10^{5}$ ind. $\left.\mathrm{m}^{-2}\right)$ conveyorbelt deposit-feeding polychaete, not only bioaccumulates DDT but also produces fecal pellets at a rate that is negatively affected by DDT in low concentrations. However, none of these studies quantified the effects of sediment-bound contaminants on the mixing behavior of this conveyor-belt deposit feeder.

The objective of this study was to quantitatively determine the effects of several sublethal concentrations of DDT on the biological mixing activities of Heteromastus filiformis within the sediment column using a non-invasive radiometric scanning technique. This 
methodology is based on an emitting radiotracer $\left({ }^{137} \mathrm{Cs}\right)$ monitored by a fully automated scan detector (Robbins et al. 1979, Keilty \& Landrum 1990).

\section{MATERIALS AND METHODS}

Sediment and polychaete collection. Marine sediments and polychaetes were collected with a brass core $(50 \mathrm{~cm}$ long, $15 \mathrm{~cm}$ diameter) from a subtidal channel in Barnstable Harbor, Cape Cod, Massachusetts. Sediment samples were placed in plastic bags in a cooler. Cores for organism collection were carefully sectioned by hand to sort out only whole individuals of Heteromastus filiformis. Individual polychaetes were initially kept in glass vials $(20 \mathrm{ml})$ containing seawater and a few drops of wet sediments (2 to $4 \mathrm{ml})$, and then transferred into a cooler half-filled with sediments. The glass vials containing the polychaetes were inserted into the sediments and the cooler filled with seawater for transportation. The collected sediments and polychaetes were transported to the laboratory within $24 \mathrm{~h}$. Once in the laboratory, the polychaetes were maintained in Instant Ocean ${ }^{\circledR}$ (Aquarium Systems) water and constantly aerated at $14^{\circ} \mathrm{C}$, and fed a natural fine sediment mixture delivered to the individual glass vials with a Pasteur pipette. Prior to the experiment, the width $(1.65 \pm 0.2 \mathrm{~mm})$ and length of the first segment with setae $(0.74 \pm 0.2 \mathrm{~mm})$ of each polychaete was measured with a dissecting microscope. The sediments were maintained at $4^{\circ} \mathrm{C}$ until use.

Sediment preparation. For the experiment, the sediments were pressed through a $250 \mathrm{~mm}$ mesh sieve to remove macroinfauna. This experimental sediment consisted of $>60 \%$ mud and fine sand, which is within the particle size range ingested by Heteromastus filiformis (Cadeé 1979, Neira \& Höpner 1993). The sediment (free of macroinfauna) was split into 4 aliquots of about 1.51 each. Three sublethal DDT concentrations were tested in this experiment: mixtures of non-radiolabeled (Chem Service) and ${ }^{14} \mathrm{C}-\mathrm{DDT}$ (Sigma, $12 \mathrm{mCi}$ $\mathrm{mmol}^{-1}$ ) at $1 \mu \mathrm{Ci}$ labeled DDT per treatment, were dissolved in $2 \mathrm{ml}$ acetone to reach final concentrations of 5, 10 and $20 \mu \mathrm{g} \mathrm{g}^{-1}$ DDT on a dry sediment basis. The radio purity of the ${ }^{14} \mathrm{C}$-DDT was $>98 \%$ and the nonlabeled compound purity was $>99 \%$. The solutions were then added to the sediments under constant suspension ( $1.5 \mathrm{l}$ wet sediment and $1.5 \mathrm{l}$ instant ocean as a seawater substitute; 34 psu final) and stirred for $2 \mathrm{~h}$. The spiked sediments were allowed to settle overnight. To remove the acetone, the overlying water was withdrawn and replaced with clean Instant Ocean ${ }^{\circledR}$ seawater. The rinsed sediment slurries were then stirred for $2 \mathrm{~h}$ and allowed to settle overnight. The overlying water was again discarded. The fourth aliquot of sediment, used as the control treatment, was subjected to the same procedure, but only $2 \mathrm{ml}$ of acetone with no DDT was added. Finally, DDT concentrations were measured for each treatment by extracting the pollutant from approximately $100 \mathrm{mg}$ of sediment (wet weight basis) using $12 \mathrm{ml}$ of scintillation cocktail (Research Products International 3a70B). This mixture was then sonicated every other second for $3 \mathrm{~min}$ and filtered. The filtered scintillation cocktail was counted for ${ }^{14} \mathrm{C}$ activity on an LKB 1217 Scintillation Counter (Wallac). The liquid scintillation cocktail served as the extracting agent for the sediment because it is a good extracting solvent (xylene based). The rinse with cyclohexane was used to ensure that all the material was washed into the cocktail. The extracts were filtered because ${ }^{137} \mathrm{Cs}$ bearing particles at the end of the experiment could have interfered while measuring labeled DDT by liquid scintillation counting. The samples were corrected for quench using the external standards ratio method after subtracting background. A second sediment subsample was taken for determination of the wet to dry weight ratio and dried at $105^{\circ} \mathrm{C}$ for $48 \mathrm{~h}$. The amount of radioactivity was used to calculate DDT concentrations on a dry sediment weight basis using the specific activity after the isotopic dilution. All values presented are mean values \pm 1 SD unless otherwise indicated. The initial measured DDT concentrations in the experimental sediments were: $5.8 \pm 1.7 \mu \mathrm{g} \mathrm{g}^{-1}$ (Treatment 1), $10.6 \pm 2.7 \mu \mathrm{g} \mathrm{g}^{-1}$ (Treatment 2) and $20.5 \pm 6.5 \mu \mathrm{g} \mathrm{g}^{-1}$ (Treatment 3) $(\mathrm{n}=3)$. The DDT distribution among sediment particles was determined for 1 replicate per treated sediment. The sample was sieved to $63 \mu \mathrm{m}$ and analyzed using a pipette analysis for the fractions below $63 \mu \mathrm{m}$ (modified from Folk 1974). DDT was determined on each fraction as described above. All the treated sediments (DDT-spiked and control) were kept at $4{ }^{\circ} \mathrm{C}$ (ca. 3 wk) until the start of the experiment.

Experimental design. A total of 15 glass microcosms $(3 \times 5 \times 30 \mathrm{~cm})$ were filled with uniformly mixed sediments that were added in layers about $2 \mathrm{~cm}$ thick alternated with submillimeter layers of ${ }^{137} \mathrm{Cs}\left(\mathrm{T}_{1 / 2}=30.2 \mathrm{yr}\right)$ sorbed to illite clay (5 to 6 layers each containing ca. $1 \mu \mathrm{Ci}$ per layer). Three replicates per treatment (control, Treatments 1, 2 and 3) were introduced into large aquaria (55 l) and kept constantly aerated (air pumps) and maintained at $14^{\circ} \mathrm{C}$ using a closed circulation system connected to a refrigerated cooler. The distribution of the microcosms into the aquaria was not random, instead the aquaria were filled with the microcosms from left to right and from controls to Treatment 3. After $48 \mathrm{~h}, 4$ polychaetes were introduced into each of the microcosms. Three replicates with no polychaetes were used as the control for sediment compaction. 
The activity and position were determined for each of the layers in each microcosm using a scan system. The basic system has been previously described (Robbins et al. 1979). For these experiments, an upgraded automated system was used (Keilty \& Landrum 1990). It consisted of a well-collimated lithium-drifted germanium detector supported on a mechanically driven elevator/platform capable of precise, repeatable movements (0.1 $\mathrm{mm}$ accuracy and repeatability) in both $x$ - and $y$-axes. The apparatus was used to vertically scan the experimental microcosms. The microcosms were scanned continuously for $64 \mathrm{~d}$ and the system completed a total scan of the microcosms every $4 \mathrm{~d}$. A scan of each microcosm was performed before the addition of the polychaetes to the microcosms.

At the end of the experiment, the microcosms were opened and the sediment column was sampled ca. every $1 \mathrm{~cm}$ (2 replicates) with a modified $25 \mathrm{ml}$ plastic syringe corer. One replicate was used for DDT measurement and the other for total organic carbon (TOC). Profiles of sediment characteristics were determined for water content, bulk density and porosity (standardized at $34 \mathrm{psu}$ and $2.65 \mathrm{~g} \mathrm{~cm}^{-3}$ ) for each microcosm. Sediment DDT concentration was measured following the procedure described earlier. Polychaetes were collected, accumulated DDT concentrations were measured (see Mulsow \& Landrum 1995 for details) and lipids were determined using a microgravimetric method based on a chloroform-methanol extraction (Gardner et al.1985). TOC was measured on powdered dry sediment $\left(105^{\circ} \mathrm{C}\right.$ for $\left.48 \mathrm{~h}\right)$ using high-temperature

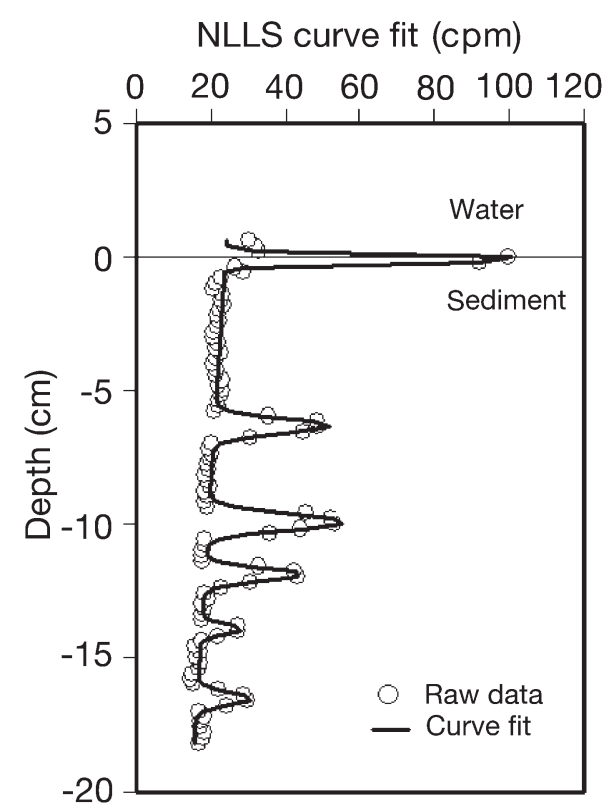

Fig. 1. Non-linear least-squares (NLLS) curve fit (-) to raw data $(\mathrm{O})$ of a selected activity profile $(\mathrm{cpm})$ showing each one of the ${ }^{137} \mathrm{Cs}$-labeled layers oxidation (CHN Perkin Elmer Analyzer) after removal of inorganic carbonates by treating the sediments within $1 \mathrm{~N} \mathrm{HCl}$. DDT degradation measurements were done on $200 \mathrm{mg}$ of sediment extracted with $50 \mathrm{ml}$ scintillation cocktail, centrifuged and decanted. A second extraction of the sediment was done with cyclohexane and the solvents combined. The extract volume was reduced to $2 \mathrm{ml}$ (rotary flash evaporation). This small sample was placed with standards of DDT, DDE and DDD, and run on a thin layer chromatographic plate of silica. After development with benzene: acetone, the bands were viewed with UV and scraped from the plate. The radioactivity in the silica gel was determined to obtain a quantitative estimation of the DDT degradation.

Interpretation of scan profiles. A representative scan of a microcosm containing several labeled layers of sediment is shown in Fig. 1. Because the detector system is well-collimated, a scan of a thin layer of emitting material produces a net counting rate profile that has a Gaussian functional form (Robbins et al. 1979):

$$
R(z)=R\left(z_{\max }\right) \mathrm{e}^{-\left(z-z_{\max }\right){ }^{2 / 2} \sigma_{\sigma}{ }_{\text {obs }}}
$$

Thus, each profile can be described in terms of 3 parameters: the depth of the maximum counting rate $\left(z_{\max }\right)$ in $\mathrm{cm}$, the width or spread in the profile $\left(\sigma_{\mathrm{obs}}\right)$ in $\mathrm{cm}$ and the maximum counting rate $\left(R_{\max }\right)$. Independent least-squares fits of Gaussian functions to layer profiles (solid line in Fig. 1) provide an acceptable representation of the data.

The observed spread ( $\sigma_{\text {obs }}$ ) is due to a combination of the actual spread in the distribution of tracer in the microcosm $(\sigma)$ and that due to the optics of the detector system $\left(\sigma_{0}\right)$. This latter value $(0.04 \mathrm{~cm})$ was determined by scanning an extremely thin layer of tracer embedded in a plastic medium. A correction for detector optics is obtained using the semi-empirical relation:

$$
\sigma^{2}=\sigma_{\mathrm{obs}}^{2}-\sigma_{\mathrm{o}}^{2}
$$

The 3 Gaussian parameters may be related to interactions of organisms with sediments. Layers of radiolabeled sediment in experimental microcosms are altered by feeding and locomotory activities of introduced infaunal benthos. First, thin-labeled layers will spread vertically as organisms mix sediments. This process has often been successfully treated being small-scale diffusive in character (Boudreau 1986), and measured in terms of a bulk sediment mixing coefficient, $D_{\mathrm{b}}$. It can be shown (Crank 1975) that $\sigma^{2}=D_{\mathrm{b}} t$, where $t$ is the time elapsed since the start of the experiment. Hence, in this study, $D_{\mathrm{b}}$ is obtained as the slope of $\sigma^{2}$ versus $t$. Second, infaunal feeding will remove radiolabeled sediments from initial layers and distribute them to other parts of microcosms, particularly to the surface for head-down feeders. While the absolute 
amount of tracer is not easily determined by the scanning method, it is proportional to the product $\sigma R_{\max }$. For the present study, extraction of tracer feeding information follows the approach Krezoski \& Robbins (1985) developed for lumbricid oligochaete feeding in tracer-labeled microcosms. They observed that a decrease in amount of tracer at a given depth (i.e. $\sigma R_{\max }$ ) was proportional to the amount remaining at a particular time, t. As a result:

$$
\left(\sigma R_{\max }\right)_{t}=\left(\sigma R_{\max }\right)_{t=0} \mathrm{e}^{-\gamma t}
$$

where $\gamma$ is the feeding rate constant $\left(\mathrm{h}^{-1}\right)$ characterizing removal of the tracer (i.e. ${ }^{137} \mathrm{Cs}$ ). Third, in the case of head-down deposit feeders such as Heteromastus filiformis, which feed well below the sediment-water interface under natural conditions, a marked layer at depth $z$ above their zone of feeding will be displaced downward as ingested sediments are removed and redeposited at the surface. The rate of layer burial is measured as $W_{\mathrm{b}}=\mathrm{d} z_{\max } / \mathrm{d} t$. In principle, $W_{\mathrm{b}}$ may be used to obtain the fundamental, biological parameter, $\gamma_{b}$, which is the rate of infaunal feeding on bulk sediment and to infer a selectivity factor $\eta=\gamma / \gamma_{\mathrm{b}}$ (Krezoski \& Robbins 1985, Robbins 1986) that measures organism preference (or lack thereof) for ingesting tracerlabeled over bulk sediment. However, effects of DDT on bulk sediment feeding can equally well be measured by $W_{\mathrm{b}}$ itself, since this study did not reveal significant selectivity (i.e. $\eta=1$ ).

\section{RESULTS}

All polychaetes were recovered alive at the end of the experiment $(64 \mathrm{~d})$. During the same time, TOC decreased in all the experimental cells (Table 1): control and Treatment 1 decreased 68 and $57 \%$, Treatments 2 and 3, 45 and $23 \%$, respectively (Table 1). Mean values of TOC in Treatments 2 and 3 at the end of the study were significantly larger than in Treatment 1 and control (Kruskal-Wallis rank test; $\mathrm{p}<0.05$ ).
Unfortunately, only the top $6 \mathrm{~cm}$ were measured for TOC. Therefore, possible changes with depth could not be observed.

By the end of the experiment, DDT sediment concentrations had decreased consistently in all the treatments from a depth of 9 to $12 \mathrm{~cm}$ to the surface (Fig. 2B). This may be the result of uptake and/or removal of the contaminant from the sediment column towards the sediment-water interface. As expected at the end of the experiment, DDT measured in Heteromastus filiformis (total body) was higher for worms exposed to the highest sediment DDT concentrations, reaching up to 4 times the DDT concentration present in sediments (Treatment 3) (Table 1).

No degradation of DDT in sediment was observed during the experimental period, and most of the DDT was parent compound (radio purity of $97 \%, \mathrm{n}=3$ ). DDT was found to be bound to particles ranging in size from 4 to 6 phi (63 to $32 \mu \mathrm{m}$ ) corresponding to medium silt size class (Folk 1974). This fraction of the sediment accounted for $59.7 \pm 7.1 \%$ of the total DDT measured in the bulk sample (Fig. 2C). We have analyzed only 1 replicate per treatment and certainly more replicates may have provided additional insight on the distribution of DDT within the sediment fractions (sand, silt and clay). This observed fractionation might be closely linked to the usually higher TOC content in the fine fraction of sediments. Nonetheless, the reported distribution indicates that DDT was primarily sorbed to particle sizes that fall within the feeding range described for Heteromastus filiformis in the field (Cadée 1979, Clough \& Lopez 1993, Neira \& Höpner 1993). Thus, $H$. filiformis is expected to be exposed through ingestion of contaminated particles as well as to DDT desorbing into porewater.

Heteromastus filiformis affects the physical characteristic of experimental sediments as observed in porosity-depth profiles (Fig. 2A). Because porosity is very sensitive to small changes in water content, handling and sampling of sediment is crucial to obtain accurate information. Porosity profiles were measured

Table 1. Experimental sediment characteristics and biological parameters of the polychaete Heteromastus filiformis. Initial $(0 \mathrm{~d})$ and final $(67 \mathrm{~d})$ total organic carbon (TOC) (\% of sediment) and average DDT concentrations ( $\left.\mu \mathrm{g} \mathrm{g}^{-1}\right)$ throughout the experiment. Final dry weight $(\mathrm{g})$ of the experimental polychaetes and bioaccumulation of DDT ( $\mathrm{g} \mathrm{g}^{-1}$ total body dry weight)

\begin{tabular}{|c|c|c|c|c|c|}
\hline \multirow[t]{3}{*}{ Treatments } & \multicolumn{3}{|c|}{ Sediment ${ }^{\mathrm{a}}$} & \multicolumn{2}{|c|}{ Polychaetes $^{\mathrm{b}}$} \\
\hline & \multicolumn{2}{|c|}{ TOC $(\%)$} & \multirow{2}{*}{$\begin{array}{c}\text { DDT concentration } \\
\left(\mu \mathrm{g} \mathrm{g}^{-1}\right)\end{array}$} & \multirow{2}{*}{$\begin{array}{l}\text { Weight } \\
(\mu g)\end{array}$} & \multirow{2}{*}{$\begin{array}{l}\text { DDT concentration } \\
\left(\mu \mathrm{g} \mathrm{g}^{-1}\right)\end{array}$} \\
\hline & Initial & Final & & & \\
\hline Control & $0.41 \pm 0.06$ & $0.13 \pm 0.02$ & - & $4.1 \pm 2.7$ & - \\
\hline Treatment 1 & $0.42 \pm 0.07$ & $0.18 \pm 0.09$ & $5.8 \pm 1.7$ & $2.7 \pm 1.1$ & $6.8 \pm 0.9$ \\
\hline Treatment 2 & $0.36 \pm 0.02$ & $0.20 \pm 0.08$ & $10.6 \pm 2.7$ & $1.2 \pm 0.9$ & $20.5 \pm 2.4$ \\
\hline Treatment 3 & $0.42 \pm 0.12$ & $0.32 \pm 0.15$ & $20.5 \pm 6.5$ & $1.1 \pm 0.7$ & $80.3 \pm 27.5$ \\
\hline
\end{tabular}




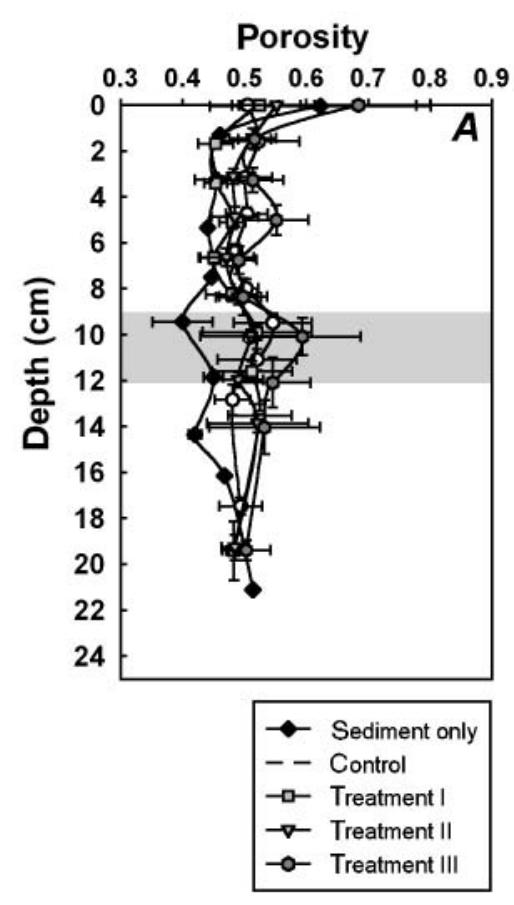

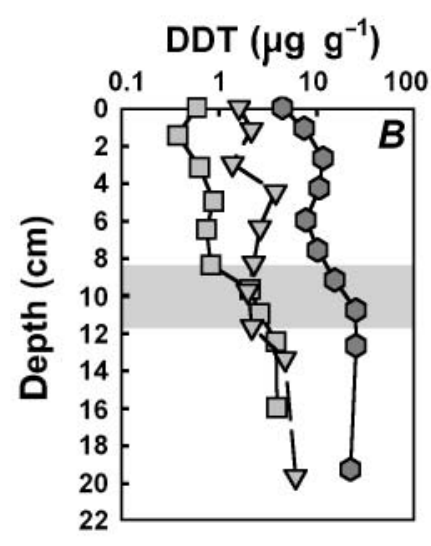

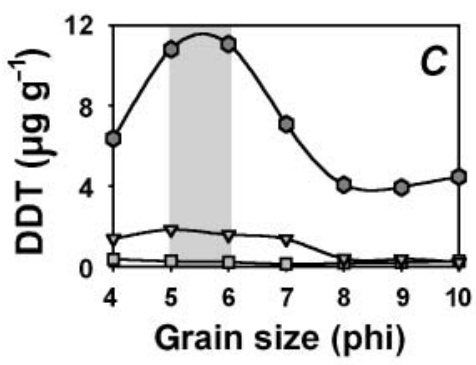

Fig. 2. Experimental sediment characteristic at the end of the experiment: (A) porosity gradients measured $(\mathrm{n}=3)$ and (B) DDT concentration gradient profiles $(n=3)$ at the end of the experiment. (C) DDT partitioning measured at the sediment fraction smaller than 63 micron (mud-clay fraction). Shaded area in (A) and (B) is an average estimate of the natural feeding depth of Heteromastus filiformis (author's pers. obs., Cadée 1979, Clought 1993). Hatched region on $(\mathrm{C})$ represents $59.6 \pm 7.1 \%$ of the total DDT found in these fractions (medium silt size; Folk 1974). Error bars in (A) and (B) represent mean values $\pm 1 \mathrm{SE}$

at the end of the experiment in all the microcosms. The data presented here are unique in the sense that one clearly can observe the increased porosity at about 9 to $12 \mathrm{~cm}$ (Fig. 2A) from $H$. filiformis bioturbation compared to surrounding values and to porosity measured in the microcosms without animals. This pattern is independent of DDT concentration. This observation must be considered when treating porosity as constant in the interpretation of radiotracer studies (Mulsow et al. 1998).

Polychaete body weight was significantly greater for those in sediments with no DDT (control: $4.1 \pm 2.7 \mathrm{mg}$ ) and Treatment $1(2.7 \pm 1.1 \mathrm{mg})$ compared to body weights measured in Treatments $2(1.2 \pm 0.9 \mathrm{mg})$ and $3(1.1 \pm 0.7 \mathrm{mg})$ (Kruskal-Wallis rank test and StudentNewman-Keuls comparison method; $\mathrm{p}<0.05)$. Although the initial polychaete weight was not determined, similar size organisms (similar size of second segment, width/length ratio, of each polychaete) were selected to be added to each of the experimental microcosms. While it was not possible to calculate growth rates, the organisms in Treatments 2 and 3 appeared to grow more slowly.

\section{Layer burial rate $\left(W_{\mathrm{b}}\right)$}

Non-linear least-square curve fits to the data proved to be a reliable technique to obtain parameterized values of the marker layer position, concentration (activity) and spreading (mixing) as previously demonstrated (Fisher et al. 1980, Robbins et al. 1984, Krezoski \& Robbins 1985). A major impact of headdown deposit feeders is the rate at which they can bury incoming particles (natural and anthropogenic) into the sediment. This ecological process plays a major role in the fate of sedimentbound exogenous compounds by reducing the time a newly settled compound is in contact with the overlying water. We estimated this process by following the burial of the top ${ }^{137} \mathrm{Cs}$ layer in each microcosm. The radiolabeled top layer was buried at a significantly faster rate in the control (no DDT) than in sediments containing DDT (Table 2). Sediment compaction was very low during the experiment $\left(0.01 \mathrm{~cm} \mathrm{wk}^{-1}\right.$; top layer; 3 replicates with no worms) and 0 in the deeper layers. This value was used to correct biological burial rates ( $W_{\mathrm{b}}$ top layer) in the control and treatments. The control burial rate $\left(4.45 \pm 0.62 \mathrm{~cm}^{\text {worm }}{ }^{-1} \mathrm{yr}^{-1}\right)$ was 1.6 times higher than for Treatment $1(2.71 \pm 0.42 \mathrm{~cm}$ worm $\left.{ }^{-1} \mathrm{yr}^{-1}\right), 2.7$ times higher than for Treatment 2 $\left(1.61 \pm 0.16 \mathrm{~cm}\right.$ worm $\left.{ }^{-1} \mathrm{yr}^{-1}\right)$ and 2.4 times the value obtained in Treatment $3\left(1.85 \pm 0.58 \mathrm{~cm}\right.$ worm $\left.^{-1} \mathrm{yr}^{-1}\right)$. All the burial rates were significantly different among treatments and control (Kruskal-Wallis rank test and Student-Newman-Keuls comparison method, $\mathrm{p}<0.05$ ).

\section{Mixing coefficient $\left(D_{b}\right)$}

In general, polychaetes exposed to 5 and $10 \mu \mathrm{g} \mathrm{g}^{-1}$ DDT showed a similar $D_{\mathrm{b}}$ profile as the control (Fig. 3). These mixing profiles demonstrated decreased mixing with depth down to 10 to $14 \mathrm{~cm}$, the approximate feeding zone of Heteromastus filiformis, where the values became similar to those at the surface, particularly for the control. This pattern was not as clear in Treatment 3. In the latter treatment, although similar values 
Table 2. Toxicological indexes: body weight, biological mixing $D_{\mathrm{B}}$, feeding rate constant $\mathrm{g}$, based on first-order kinetics (lnA vs $t$ ) and burial rate $\left(W_{\mathrm{b}}\right)$. Rate of change is also given. ${ }^{*} \mathrm{p}<0.05$

\begin{tabular}{|c|c|c|c|c|}
\hline & \multicolumn{4}{|c|}{ Toxicological indexes } \\
\hline & Body weight (mg) & $W_{\mathrm{b}}\left(\mathrm{cm} \mathrm{w}^{-1} \mathrm{yr}^{-1}\right)$ & $D_{\mathrm{B}}\left(\mathrm{cm}^{2} \mathrm{yr}^{-1}\right)^{\mathrm{a}}$ & $\gamma\left(\% \mathrm{~h}^{-1}\right) \times 10^{-3 \mathrm{a}}$ \\
\hline Control & $4.1 \pm 2.7$ & $4.45 \pm 0.62$ & $0.88 \pm 0.18$ & $0.23 \pm 0.08$ \\
\hline Treatment 1 & $2.7 \pm 1.1$ & $2.71 \pm 0.42$ & $0.75 \pm 0.51$ & $0.06 \pm 0.05$ \\
\hline Treatment 2 & $1.2 \pm 0.9$ & $1.61 \pm 0.16$ & $0.74 \pm 0.44$ & $0.07 \pm 0.03$ \\
\hline Treatment 3 & $1.1 \pm 0.7$ & $1.85 \pm 0.58$ & $0.55 \pm 0.12$ & $0.07 \pm 0.09$ \\
\hline $\mathrm{RC}\left(\mu \mathrm{g}^{-1} \mathrm{~g}^{-1}\right)$ & $0.09 \pm 0.02$ & $0.07 \pm 0.03$ & $0.02 \pm 0.004$ & $0.14 \pm 0.07$ \\
\hline$r^{2}$ & 0.93 & 0.79 & $0.95^{*}$ & 0.70 \\
\hline
\end{tabular}

for surface mixing were observed, mixing at depth was less pronounced and represented by lower values. Perhaps a more defined pattern could have been observed if the experiment had lasted longer. The time constraint comes from the non-steady state conditions of the experimental design. The organic carbon source is finite and decreases significantly over the course of the experiment (Table 1), and the geochemical milieu is controlled to a great extent by external aeration. Controlling the temperature of the sediment column

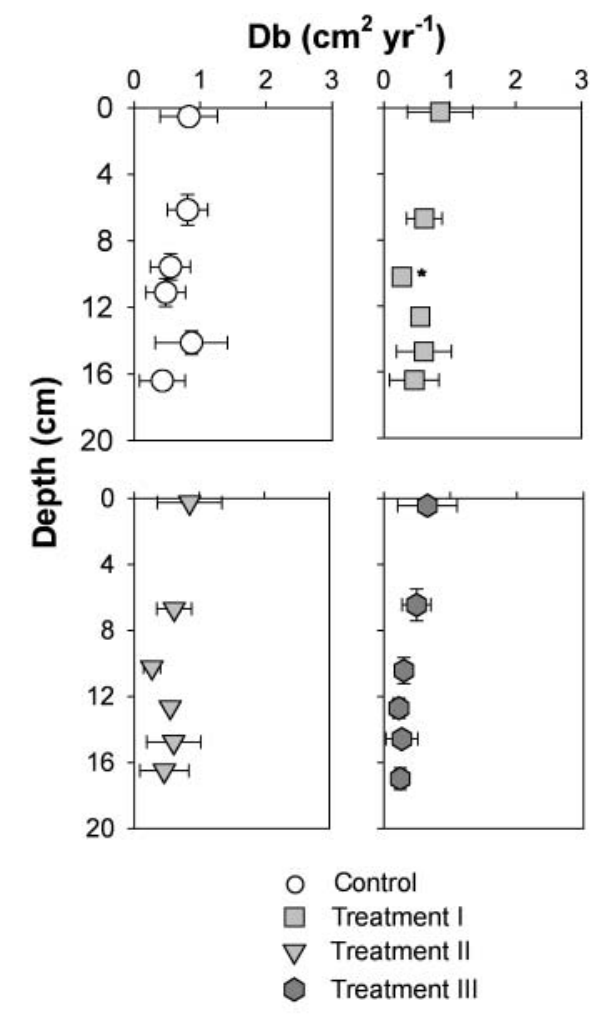

Fig. 3. Mixing coefficients determined for each layer for all treatments and the control. $D_{\mathrm{b}}$ values are mean values $\pm 1 \mathrm{SD}$ of at least 3 replicates with the exception of Treatment $1\left(^{*}\right)$. In this latter case, only 1 microcosm had that particular layer marked with ${ }^{137} \mathrm{Cs}$ only reduces the microbial degradation of the sediment column and thus avoidance of anoxic conditions in the microcosms.

\section{Feeding rate constant $\left(\gamma_{b}\right)$}

Feeding rate constant $\left(\gamma_{\mathrm{b}}, \% \mathrm{~h}^{-1}\right)$ was calculated for each peak and was clearly a Gaussian-like function for the control. The treatments clearly showed an essentially constant $\gamma_{b}$ pattern (Fig. 4) that was basically independent of the DDT concentration but substantially different from the control. The feeding rate constant was generally constant with depth and lower

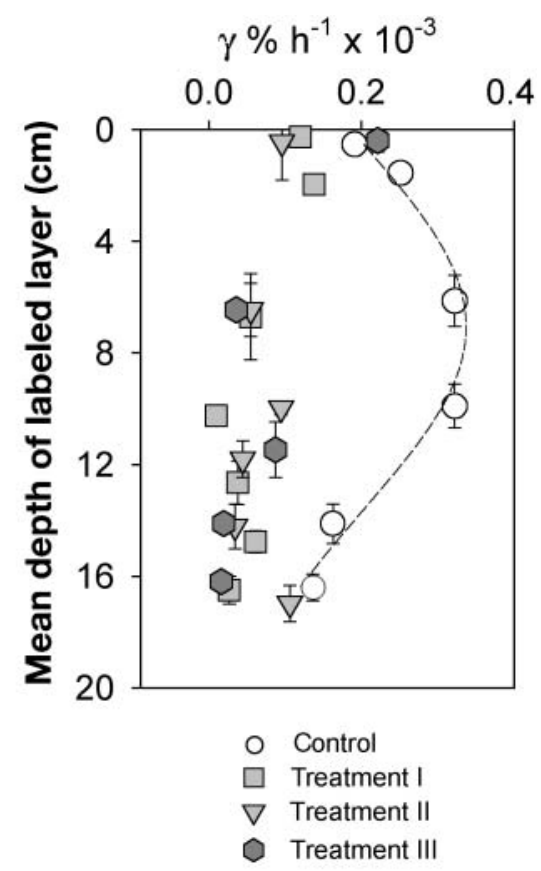

Fig. 4. Feeding rate constant $(\gamma)$ calculated for each layer. Only the control appears to have a Gaussian-like function with depth, showing a maximum $\mathrm{g}$ at depth of 7 to $12 \mathrm{~cm}$ below the surface. Dashed line: Gaussian fit curve. Mean depth layer $\pm 1 \mathrm{SD}$ 


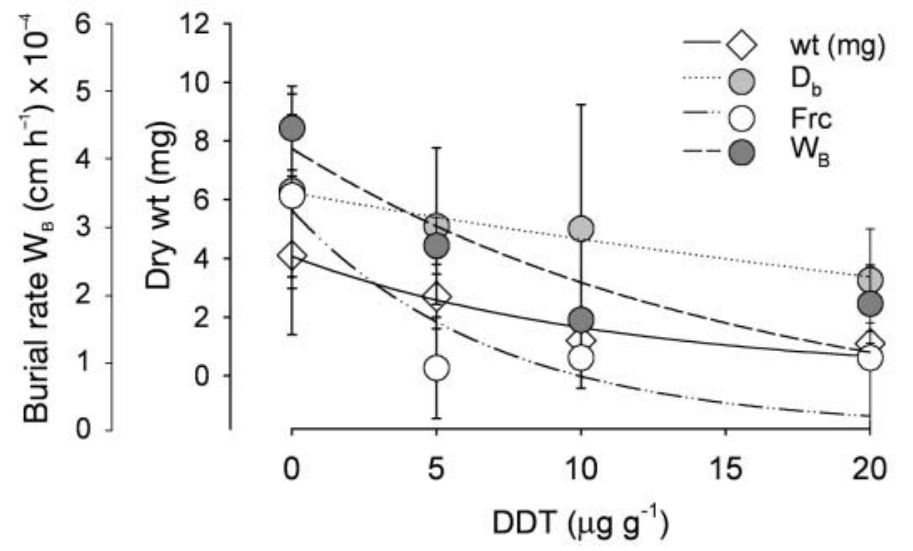

than that for the control for all the treatments. Further, feeding appears to be largely restricted to nearsurface sediments for the DDT treatments (Fig. 4). In general, the values are small compared to those reported for a freshwater annelid (Krezoski \& Robbins 1985). Nonetheless, Heteromastus filiformis is a well known head-down deposit feeder; thus, the observed subsurface peak for $\gamma_{\mathrm{b}}$ in this study confirms the polychaete's feeding behavior by showing a maximum in the range of 7 to $12 \mathrm{~cm}$ (Fig. 4). Perhaps the differences between control and treatments makes this parameter a very sensitive one that would enable the detection of the impact of sediment-bound contaminants on this species.

A sensitivity analysis among the parameters determined in this study (Table 2, Fig. 5) was carried out as a function of DDT concentration. This comparison showed that: (1) all the parameters decreased with increasing DDT concentration; and (2) the relationships were apparently non-linear. Only $D_{\mathrm{b}}$ versus DDT showed a significant correlation coefficient $\left(\mathrm{r}^{2}=0.95\right.$, $p<0.05)$. The feeding rate constant $\left(\gamma_{b}\right)$ showed the highest fraction change $\mu^{-1} \mathrm{~g}^{-1}$ DDT of all the parameters $(0.14 \pm 0.07)$ but also the lowest correlation coefficient (0.7). Body weight and burial rate exhibited a fractional rate change of $0.09 \pm 0.02$ and $0.07 \pm$

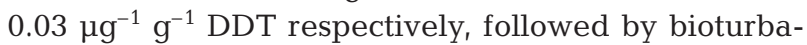
tion coefficient $\left(D_{\mathrm{b}}\right)$ at $0.02 \pm 0.004 \mu \mathrm{g} \mathrm{DDT}^{-1}$. Although body weight fractional change was the second-most sensitive endpoint, caution should be used in its interpretation. It is clear that the time of our experiment was rather short to clearly define the effects of DDT in the parameters chosen. $D_{\mathrm{b}}$ was the only parameter significantly affected by DDT concentration in sediments; thus, given the short duration of the experiment represents a comprehensive parameter describing the biological effect of Heteromastus filiformis in sediment mixing while this species is exposed to sediment-bound contaminants like DDT.

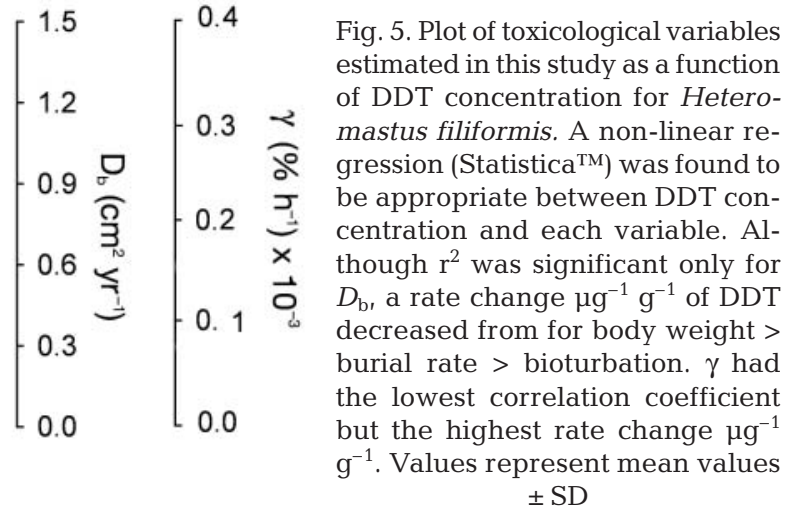

\section{DISCUSSION}

There was a considerable decrease in the amount of TOC at the end of the experiment that ranged from 44 to $71 \%$ of the initial TOC content. If the amount of required organic matter by $1 \mathrm{mg}$ (dry weight) Heteromastus filiformis is roughly $0.004 \mathrm{mg} \mathrm{C} \mathrm{d}^{-1}$ (Clought \& Lopez 1993), then the experimental sediment column had several times more TOC even at the end of the experiment than that required by the largest worms (4 mg, control). Thus, TOC was not likely a limiting factor in our study. Therefore, the observed effects on the biological mixing activities of $H$. filiformis may be attributed to DDT. If the ratio of labile to refractory organic matter was very small, then the effect of TOC depletion may have played a role and somewhat masked the effect of DDT. However, $H$. filiformis in nature feeds at depth where the labile to refractory ratio is also small compared to the surface newly settled organic particles. Thus, the ratio of labile to refractory carbon may not account for the observed effect on the biological activity of $H$. filiformis. Another factor that could have played a role in the observed results is the size of the worms used in the experiment. However, the initial width/length ratio was not different among the worms used. Thus, most of the response of $H$. filiformis must be related to the presence of the contaminant (DDT) in the sediment.

The presence of sub-lethal concentrations of DDT in sediments modifies rates of sediment mixing and feeding by Heteromastus filiformis. Polychaetes not exposed to DDT produced mixing rate coefficient $\left(D_{\mathrm{b}}\right)$ profiles that initially decrease and then increase slightly between about 12 to $16 \mathrm{~cm}$ depth. This slight increase in $D_{\mathrm{b}}$ was most prominent in the control cells, still somewhat evident in Treatments 1 and 2 but absent in Treatment 3 cells, where $D_{\mathrm{b}}$ declined down core (Fig. 3). The effects of bioturbation were clearly manifested by changes observed within the same 
depth range in porosity, DDT concentration and feeding rate $\left(\gamma_{b}\right)$ profiles. This biological mixing depth corresponds to the depth at which $H$. filiformis has been observed to feed in nature (10 to $20 \mathrm{~cm}$ below the surface) (Cadée 1979, Neira \& Höpner 1993, 1994). However, in each case, the more or less linear decreases in mixing rate coefficient $\left(D_{\mathrm{b}}\right)$ from the sediment surface, followed by an increase in the vicinity of the feeding zone, are consistent with the modality of this deposit feeder. In the region from the top down to the worm's range of feeding, sediments are mixed primarily by full-length body motions that will be most marked in least consolidated (i.e. higher-porosity) sediments. Within the feeding zone, sediment mixing will undoubtedly be intensified by activities of recruiting, ingesting and rejecting sediment nutrients. In Fig. 4, it is clear that in the absence of DDT (control), feeding is distributed over a broad depth range. In all other cases, feeding is much lower and evidently confined to the near-surface sediments, although in Treatments 1 and 2 , there is a suggestion of an increase around $12 \mathrm{~cm}$ depth. Even at the lowest concentration employed $\left(5 \mathrm{~g} \mathrm{~g} \mathrm{~g}^{-1}\right)$, DDT appears to have an effect on the magnitude as well as the distribution of feeding by $H$. filiformis. The DDT-associated decrease in feeding rate is linked, as might be expected, by a reduction in the rate of sediment mixing within or near the terminus of the zone of feeding. However, the initial linear decrease in $D_{\mathrm{b}}$ is largely unaffected by the presence of added DDT in the concentration range of 0 to $20 \mu g \mathrm{~g}^{-1}$. Thus, DDT interfered with normal rates and distributions of feeding by $H$. filiformis, but had little effect on their mixing of sediments above the feeding zone.

Heteromastus filiformis was negatively affected by the presence of DDT. The sensitivity analysis depicted body weight more sensitive than $W_{\mathrm{B}}$ and $D_{\mathrm{b}}$ of the parameters used in this study as a function of the contaminant concentration. Worms exposed to the lowest DDT concentration $\left(5 \mathrm{\mu g} \mathrm{g}^{-1}\right)$ showed somewhat similar patterns of mixing rates profiles compared to the controls but with lower mixing and burial rates. When $H$. filiformis was subjected to DDT concentrations of $10 \mathrm{\mu g} \mathrm{g}^{-1}$ or more (particularly Treatment 3 ), the mixing-rates were rather constant throughout the sediment column (no clear subsurface peak) and significantly lower than for Treatments 1,2 and the control (Fig. 3). The presence of DDT in sediment also reduced the feeding rate constant of the polychaetes, even at the lowest treatment concentration $5 \mu \mathrm{g} \mathrm{g}^{-1}$ (Fig. 4). Apparently, $H$. filiformis under these experimental conditions reduces its feeding at the lowest concentration, while the average mixing rate coefficient $\left(D_{\mathrm{b}}\right)$ is less affected requiring a sediment DDT concentration of $>10 \mu \mathrm{g} \mathrm{g}^{-1}$ to show a clear decline. Perhaps after exposure to the contaminant, the worms reduce their feeding rate and only mix the sediments diffusively and convey only limited amounts of ingested sediment to the surface. Thus, the burial rate remains low compared to the control while mixing continues. The worms may continue to accumulate DDT by routes other than ingestion as Clought \& Lopez (1993) have suggested it (wall absorption of dissolved organic compounds). Overall, the impact of accumulated DDT follows a simple rule: The more contaminant in the sediment, the more the body burden. Similar findings have already been reported for $H$. filiformis. At a DDT concentration of $8 \mu \mathrm{g} \mathrm{g}^{-1}$, a significant reduction in fecal pellet production (and hence feeding rate) was observed after a short period of exposure (28 d) (Mulsow \& Landrum 1995).

The biological burial rate in the control $\left(4.5 \mathrm{~cm} \mathrm{yr}^{-1}\right.$; Table 2) was comparable to 'reworking rates' measured in the field for Heteromastus filiformis: Cadée (1979) reported $3.9 \mathrm{~cm} \mathrm{yr}^{-1}$ and Neira \& Höpner (1993) found $5.96 \mathrm{~cm} \mathrm{yr}^{-1}$.

Post-experimental worm dry weights were inversely related to the concentration of the contaminant, reflecting, perhaps, a decrease in feeding and reworking rate and/or stress associated with the levels of DDT in the sediments. Because initial weights were not determined, it is not certain whether the controls grew faster or the DDT-exposed worms at the higher treatments lost weight due to reduced feeding.

The use of non-invasive techniques, such as the one reported here, clearly demonstrate the high resolution at which one can quantitatively measure and describe the complex feeding behavior of marine invertebrates that live and feed beneath the sediment-water interface. Biological mixing rate $D_{\mathrm{b}}$ showed here to be a very powerful parameter to describe the overall mixing activity of this polychaete while exposed to environmental stress caused by a sediment-bound contaminant. However, this experiment also shows that feeding study is of such complexity that a sole parameter such as $D_{\mathrm{b}}$ or $\gamma_{\mathrm{b}}$ cannot be used independently as an index for estimation of the effect on the feeding behavior of Heteromastus filiformis. At sub-lethal concentrations, DDT produces a complex response of the organism, which may be revealed by a multi-parametric non-invasive radiotracer scanning method such as the one employed in this study. While $D_{\mathrm{b}}$ in the presence of DDT did not show a large difference compared to the control over the whole sediment column, it was enough to significantly decrease with increasing DDT concentration. Both body weight and burial rate $\left(W_{\mathrm{b}}\right)$ had higher fractional rate of change than $D_{\mathrm{b}}$ with DDT concentration, and are the more sensitive parameters to demonstrate the impact of DDT on $H$. filiformis for future experiments. Finally, truly marine deposit feeders, in particular head-down conveyor-belt deposit 
feeders such as $H$. filiformis, are species prone to be affected by the introduction of many sediment-bound chemical compounds in a very short time period, as these species feed on sediments. Perhaps sub-lethal concentrations may eventually have a long-lasting effect on the overall benthic assemblage. Although species may not necessarily be eliminated, changes in the rate at which these species mix sediments will alter important diagenetic reactions.

Acknowledgements. This research was performed at the Great Lakes Environmental Research Laboratory, NOAA, Ann Arbor, MI. We wish to thank S. W. Fowler for review of a previous version of the manuscript. We would also like to thank 2 anonymous reviewers for their valuable comments and improvement of the manuscript. The work was funded by a grant from the US Environmental Protection Agency, Grant N R-817278-01-1. Although the information in this document was funded in part by the US EPA, it may not necessarily reflect the views of the agency. No official endorsement should be inferred. Mention of trade names and commercial products does not constitute endorsement or recommendation for use. This is GLERL contribution No. 1226.

\section{LITERATURE CITED}

Aller RC (1980) Diagenetic processes near the sedimentwater interface of Long Island Sound. I. Decomposition and nutrient element geochemistry $(\mathrm{S}, \mathrm{N}, \mathrm{P})$. In: Saltzman B (ed) Estuarine physics and chemistry: studies in Long Island Sound. Advances in geophysics, Vol 22. Academic Press, New York, p 237-250

Aller RC, Dodge RE (1974) Animal-sediment relations in a tropical lagoon, Discovery Bay, Jamaica. J Mar Res 32: 209-232

Amiard-Triquet C (1974) Etude experimentale de la contamination par le $144 \mathrm{Ce}$ et le $59 \mathrm{Fe}$ d'un sediment a Arenicola marina L. (Annelide, polychaete). Biol Mar 15:483-494 (in French with English Abstract)

Appleby AG, Brinkhurst RO (1970) Defecation rate of three tubificid oligochaetes found in the sediment of Toronto Harbor, Ontario. J Fish Res Board Can 27:1971-1982

Berg V, Ugland KI, Hareide NR, Aspholm PE, Polder A, Skaare JU (1997) Organochlorine contamination in deepsea fish from the Davis Strait. Mar Environ Res 44:135-148

Berner RA (1980) Early diagenesis: a theoretical approach. Princeton University Press, Princeton, NJ

Boudreau BP (1986) Mathematics of tracer mixing in sediments. I. Spatially-dependent, diffusive mixing. Am J Sci 286:161-198

Cadée CC (1979) Sediment reworking by the polychaete Heteromastus filiformis on a tidal flat in the Dutch Wadden Sea, Netherlands. J Sea Res 13:441-456

Cammen LM (1980) Ingestion rate: an empirical model for aquatic deposit feeders and detritivores. Oecologia 44: 303-310

Cantillo AY, Lauestein GG, O'Connor TP (1997) Mollusc and sediment contaminant levels and trends in south Florida coastal waters. Mar Pollut Bull 34:511-521

Clough LM, Lopez GR (1993) Potential carbon sources for the head-down deposit-feeding polychaete Heteromastus filiformis. J Mar Res 51:595-616

Crank J (1975) The mathematics of diffusion. Clarendon Press, Oxford
Davis RB (1974) Stratigraphic effects of tubificids in profundal lake sediments. Limnol Oceanogr 15:41-58

Dexter RN, Pavlou SP (1973) Chlorinated hydrocarbons in sediments from southern Greece. Mar Pollut Bull 4: $180-190$

Elder DL, Parsi P, Harvey GR (1976) Polychlorinated biphenyl in seawater, sediments and over ocean air of the Mediterranean. In: Activities of the International Laboratory of Marine Radioactivity Report. International Atomic Energy Agency, Vienna, p 136-151

Elder DL, Fowler SW, Polikarpov GG (1979) Remobilization of sediment-associated PCBs by the worm Nereis diversicolor. Bull Environ Contam Toxicol 21:448-452

Fisher JB, Lick WJ, McCall PL, Robbins JA (1980) Vertical mixing of lake sediments by tubificid oligochaetes. J Geophys Res 85:3997-4006

Folk R (1974) Petrology and sedimentary rocks. Hemphill Publishing, Austin, TX

Fowler SW, Polikarpov GG, Elder DL, Villeneuve JP (1978) Polychlorinated biphenyl: accumulation from contaminated sediments and water by the polychaete Nereis diversicolor. Mar Biol 48:303-309

Frankel E (1995) Ocean environmental management. Prentice-Hall, New York

Gardner WS, Frez WA, Cichocki EA (1985) Micromethod for lipids in aquatic invertebrates. Limnol Oceanogr 30: 1099-1105

Gilbert F, Rivet L, Bertrand JC (1995) The in vitro influence of the burrowing polychaete Nereis diversicolor on the fate of petroleum hydrocarbons in marine sediments. Chemosphere 29:1-12

Haven DS, Morales-Alamo R, Kraeuter JN (1981) Sediment mixing by invertebrates as shown by $85 \mathrm{Kr}$. Special Scientific Report No. 109. Virginia Inst Mar Sci, Gloucester Point, VA

Heemken OP, Stachel B, Theobald N, Wenclawiak BW (2000) Temporal variability of organic micropollutants in suspended particulate matter of the River Elbe at Hamburg and the River Mulde at Dessau, Germany. Arch Environ Contam Toxicol 38:11-31

Hom W, Risenbrough RW, Soutar A, Young DR (1974). Deposition of DDE and polychlorinated biphenyl in dated sediments of Santa Barbara Basin. Science 184:1179-1199

HSDB (Hazardous Substances Data Bank) (1998) The Department of Health \& Human Services, National Library of Medicine, Division of Specialized Information Services, Toxicology and Environmental Health Information Program (TEHIP), Bethesda, MD

Hylleberg J (1975) Selective feeding by Abarenicola pacifica with selective notes on Abarenicola vagabunda and a concept of gardening in lugworms. Ophelia 14:113-137

Keilty TJ, Landrum PF (1990) Population-specific toxicity responses by the freshwater oligochaete, Stylodrilus heringianus in natural Lake Michigan sediments. Environ Toxicol Chem 9:1147-1154

Keilty TJ, White DS, Landrum PF (1988a) Sublethal responses to endrin in sediment by Stylodrilus heringianus (Lumbriculidae) as measured by a 137-cesium marker layer technique. Aquat Toxicol 13:251-270

Keilty TJ, White DS, Landrum PF (1988b) Sublethal responses to endrin in sediment by Limnodrilus hoffmeisteri (Tubificidae) alone and with Stylodrilus heringianus (Lumbriculidae). Aquat Toxicol 13:227-250

Krezoski JR (1981) The influence of zoobenthos on finegrained particle reworking and benthic solute transport in Great Lakes sediments. PhD thesis, University of Michigan, Ann Arbor 
Krezoski JR, Robbins JA (1985) Vertical distribution of feeding and particle-selective transport of ${ }^{137} \mathrm{Cs}$ in lake sediments by lumbriculid oligochaetes. J Geophys Res 90: $7937-7947$

Levinton J (1989) Deposit-feeding in coastal oceanography. In: Lopez GR, Taghon GL, Levinton J (eds) Ecology of marine deposit feeders. Springer-Verlag, New York, p 1-23

Lopez G, Cheng IJ (1983) Synoptic measurements of ingestion rate, ingestion selectivity, and absorption efficiency of natural foods in the deposit-feeding mollusk Nucula annulata (Bivalvia) and Hydrobia totteni (Gastropoda). Mar Ecol Prog Ser 11:55-62

Mahaut ML, Graf G (1987) A luminophore tracer technique for bioturbation studies. Oceanol Acta 10:323-328

Marcus JM, Renfrow RT (1990) Pesticides and PCBs in South Carolina estuaries. Mar Pollut Bull 21:96-99

Marcus N, Schmidt-Gengenbach J (1986) Recruitment of individuals into the plankton: the importance of bioturbation. Limnol Oceanogr 31:206-210

McCall PL, Fisher JB (1980) Effects of tubificid oligochaetes on physical and chemical properties of lake sediments. In: Brinkhurst RO, Cook DG (eds) Aquatic oligochaete biology. Plenum Press, New York, p 253-317

McCall PL, Tevesz MJS (1982) The effects of benthos on physical properties of freshwater sediments. In: McCall PL, Tevesz MJS (eds) Animal-sediment relations: the biogenic alteration of sediments. Plenum Press, New York, p 105-176

Mulsow S, Landrum PF (1995) Bioaccumulation of DDT in a marine polychaete, the conveyor-belt deposit feeder Heteromastus filiformis (Claperede). Chemosphere 31: 3141-3152

Mulsow S, Boudreau B, Smith JN (1998) Bioturbation and porosity gradients. Limnol Oceanogr 43:1-9

Neira C, Höpner T (1993) Fecal pellet production and sediment reworking potential of Heteromastus filiformis show a tide dependent periodicity. Ophelia 37:175-185

Neira C, Höpner T (1994) The role of Heteromastus filiformis (Capitellidae, Polychaeta) in organic carbon cycling. Ophelia 39:55-73

Olmez I, Pink FX, Wheatcroft RA (1994) New particle-labeling technique for use in biological and physical sediment transport studies. Environ Sci Technol 28:1487-1490

Rhoads DC (1963) Rates of sediment reworking by Yoldia limatula in Buzzards Bay, Massachusetts and Long Island Sound. J Sediment Petrol 33:723-727

Rhoads DC (1974) Organism-sediment relations on the muddy seafloor. Oceanogr Mar Biol Annu Rev 12:263-300

Rice DL (1986) Early diagenesis in bioadvective sediments: relationships between the diagenesis of berillium-7, sediment reworking rates and the abundance of conveyor-belt deposit-feeders. J Mar Sci 44:149-184

Editorial responsibility: Otto Kinne (Editor),

Oldendorf/Luhe, Germany
Rice DL, Bianchi TS, Roper AE (1986) Experimental studies of sediment reworking and growth of Scoloplos spp. (Orbiniidae: Polychaeta). Mar Ecol Prog Ser 30:9-19

Rice DL, Craig CP, Seltenrich R, Spies RB, Keller M (1993) Seasonal and annual distribution of organic contaminants in marine sediments from Elkhorn Sloughs, Moss Landing Harbor and Nearshore Monterey Bay, California. Environ Pollut 82:79-91

Robbins JA (1986) A model for particle-selective transport of tracers in sediments with conveyor-belt deposit feeders. J Geophys Res 91:8542-8558

Robbins JA, McCall PL, Fisher JB, Krezoski JR (1979) Effect of deposit feeders on migration of ${ }^{137} \mathrm{Cs}$ in lake sediments. Earth Planet Sci Lett 42:277-287

Robbins JA, Husby-Coupeland K, White DS (1984) Precise radiotracer measurements of the rate of sediment reworking by Stylodrilus heringianus: effects of variable dissolved oxygen levels. J Great Lakes Res 4:335-341

Santschi PH, Nyffeler UP, Ohara P, Bucholtz M, Broecker WS (1984) Radiotracer uptake on the seafloor: results from MANOP chamber deployments in the eastern Pacific. Deep-Sea Res 25:953-965

Schiff KC (1991) The effect and accumulation of sedimentadsorbed DDT in the polychaete, Capitella capitata. Bull Mar Sci 48:594

Sorokin JI (1986) Carbon-14 method in the study of the nutrition of aquatic animals. Int Rev Gesamt Hydrobiol 51: 209-224

Takahashi S, Lee J, Tanabe S, Kubodera T (1998) Contamination of organochlorine and butyltin compounds in deepsea organisms collected from Suruga Bay, Japan. Sci Total Environ 214:49-64

Thayer CW (1983) Sediment mediated biological disturbance and the evolution of marine benthos. In: Tevesz M, McCall PL (eds) Biotic interactions in recent and fossil benthic communities. Plenum Press, New York, p 480-625

Verschueren K (1983) Handbook of environmental data on organic chemicals. Van Nostrand Reinhold, New York

Wheatcroft RA, Martin WR (1996) Spatial variation in shortterm ${ }^{235} \mathrm{Th}$ sediment bioturbation intensity along an organic-carbon gradient. J Mar Res 54:763-792

Whitlach RB, Weinberg JR (1982) Factors influencing particle selection and feeding rate in the polychaete Cystenides (Pectinaria) gouldii. Mar Biol 71:33-40

Young DR, McDermont-Ehrlich D, Heesen TC (1977) Sediments as sources of DDT and PCB. Mar Pollut Bull 8: $245-257$

Young DR, Means AJ, Gossett RW (1991) Bioaccumulation of p, p'-DDE and PCB 1254 by a flatfish bioindicator from highly contaminated marine sediments of southern California. In: Baker RA (ed) Organic substances and sediments in water: Biological, Vol 3. Lewis Publishers, Ann Arbor, MI, p 159-169

Submitted: June 18, 2001; Accepted: April 4, 2002

Proofs received from author(s): July 31, 2002 